\title{
Catatan Penelitian
}

\section{Pengaruh Whey dan Ekstrak Buah terhadap Total Bakteri Asam Laktat, Nilai pH, dan Adhesiveness Yoghurt}

\author{
(The Influence of Whey and Fruit Extracts on Lactic Acid Bacteria, pH, and Adhesiveness of Yoghurts \\ Made of Farmer's Milk) \\ Wihardi, Christina Budiarti, Setya Budi Muhammad Abduh, Ahmad Ni'matullah Al-Baarri, Yoyok Budi Pramono \\ Fakultas Peternakan dan Pertanian Universitas Diponegoro Semarang \\ Korespondensi penulis: setya.abduh@undip.ac.id \\ Artikel ini dikirim pada tanggal 1 Juni 2015 dan dinyatakan diterima tanggal 15 Agustus 2015. Artikel ini juga dipublikasi secara online melalui \\ www.journal.ift.or.id. Hak cipta dilindungi undang-undang. Dilarang diperbanyak untuk tujuan komersial. \\ Diproduksi oleh Indonesian Food Technologists® @2015 (www.ift.or.id)
}

\begin{abstract}
Abstrak
Penelitian ini bertujuan untuk mengevaluasi pengaruh whey dan ekstrak buah, antara lain alpukat, salak, dan lengkeng dalam yoghurt untuk Bakteri Asam Laktat (BAL), $\mathrm{pH}$, dan adhesiveness yoghurt bahan baku susu peternakan rakyat. Yoghurt dibuat melalui beberapa langkah, yaitu formulasi, inaktivasi bakteri oleh sistem Lactoperoxidase (LPOs) selama 30 menit, BAL inokulasi pada $3 \%(\mathrm{v} / \mathrm{v})$, dan inkubasi pada $37{ }^{\circ} \mathrm{C}$ selama 4 jam. Sebagai perlakuan, yoghurt diperkaya dengan whey dan ekstrak buah $(3 \%, v / v)$ sebelum inaktivasi oleh bakteri. $\mathrm{BAL}, \mathrm{pH}$, dan adhesiveness diamati setiap jam. Kualitas yoghurt yang diperkaya dengan whey, alpukat, salak, dan lengkeng diukur pada jam ke-4 inkubasi. BAL untuk whey, alpukat, salak, lengkeng dan yoghurt kontrol masingmasing adalah 7,$01 ; 7,21 ; 7,19 ; 7,13$; dan $7,17 \mathrm{log} \mathrm{cfu} / \mathrm{ml}$. Nilai $\mathrm{pH}$ yang diperoleh untuk whey, alpukat, salak, lengkeng dan kontrol yoghurt masing-masing adalah 5,$11 ; 4,61 ; 4,68 ; 4,67$; dan 4,77, sedangkan adhesiveness masing-masing 2,$56 ; 3,13 ; 2,70 ; 3,13 ; 2.96$ gs. Semua hasil antar perlakuan tidak berbeda nyata. Dapat disimpulkan bahwa tambahan whey dan ekstrak buah-buahan di yoghurt memberikan kualitas yang sama $(P>$ $0,05)$ dan memenuhi SNI. Selain itu, ekstrak alpukat di yoghurt mengakibatkan tingkat pertumbuhan tercepat spesifik inokulum, yaitu sebesar 0,67 CFU/s.
\end{abstract}

Kata kunci : yoghurt, whey, ekstrak buah, BAL, pH dan adhesiveness

\begin{abstract}
Abstrak
This research was aimed to evaluate the influence of whey and fruit extracts, i.e. avocado, salak, and longan present in yoghurt to its Lactic Acid Bacteria ( $L A B), p H$, and adhesiveness of yoghurt made of farmer's milk. Yoghurt was made by several steps, such as formulation, bacterial inactivation by Lactoperoxidase system (LPOs) for $30 \mathrm{~min}, \mathrm{LAB}$ inoculation at $3 \%(\mathrm{v} / \mathrm{v})$, and incubation at $37^{\circ} \mathrm{C}$ for $4 \mathrm{~h}$. As treatments, whey and fruit extracts $(3 \%$, $\mathrm{v} / \mathrm{v}$ ) were fortified prior to the bacterial inactivation. $\mathrm{LAB}, \mathrm{pH}$, and adhesiveness were monitored hourly. The quality of those fortified with whey, avocado, salak, and longan were measured at the hour 4 of incubation. The LAB for whey, avocado, salak, longan and yoghurt control were $7.01 ; 7.21 ; 7.19 ; 7.13$; and $7.17 \mathrm{log} \mathrm{cfu} / \mathrm{ml}$, respectively. The $\mathrm{pH}$ values were $5.11 ; 4.61 ; 4.68 ; 4.67$; and 4.77 , for whey, avocado, salak, longan and yoghurt control respectively, while the adhesiveness were $2.56 ; 3.13 ; 2.70 ; 3.13 ; 2.96 \mathrm{gs}$, respectively. All the results among the treatments were not significantly different. It can be concluded that whey and fruits extract in yoghurt were in similar quality $(P>0.05)$ and met the SNI. Moreover, avocado extract in yoghurt resulted in the fastest specific growth rate of inoculum, being $0.67 \mathrm{CFU} / \mathrm{s}$.
\end{abstract}

Keywords: yoghurt, whey, fruit extract, LAB, pH, and adhesiveness

\section{Pendahuluan}

Citarasa asam pada yoghurt kadang-kadang menyebabkan yoghurt kurang disukai konsumen. Penambahan whey dan ekstrak buah berguna untuk membantu meningkatkan kandungan nutrisi pada susu segar dengan harapan dapat meningkatkan kualitas dan citarasa yoghurt. Ekstrak buah telah digunakan sebagai bahan tambahan dalam yoghurt untuk menciptakan citarasa yang menarik. Beberapa ekstrak buah seperti nangka (Azizah et al., 2013), jambu air (Purbasari et al., 2014), nanas (Insyiroh et al., 2014), dan kelengkeng (Puspitasari et al., 2014) telah digunakan dan menghasilkan mutu yoghurt dengan kandungan BAL yang relatif beragam. Sebagian menimbulkan efek pertumbuhan BAL yang lebih tinggi dibanding tanpa ekstrak buah, dan sebagian lainnya menunjukkan sebaliknya. Variasi efek yang ditimbulkan diduga berkaitan dengan komposisi gula pada setiap ekstrak buah yang berbeda, satu dengan yang lainnya. Fenomena ini menjadi menarik mengingat bahwa total BAL merupakan atribut mutu yang penting pada yoghurt, apalagi ketika yoghurt yang dikembangkan adalah yoghurt probiotik. Oleh karenanya, sumber gula alami lain yang relatif belum dimanfaatkan berpotensi untuk dicobakan, misalnya whey.

Penelitian ini bertujuan untuk mengevaluasi efek kehadiran whey dan ekstrak buah alpokat, salak dan kelengkeng dalam yoghurt terhadap terhadap total BAL, 
nilai $\mathrm{pH}$, dan adhesiveness yoghurt berbahan baku susu segar dari peternakan serta mengevaluasi substrat mana yang lebih baik dalam mempercepat waktu fermentasi.

\section{Materi dan Metode}

Yoghurt dibuat melalui tahapan formulasi, inaktivasi bakteri dengan sistem LPO sebanyak 20\% selama 30 menit, inokulasi BAL sebanyak $3 \%(\mathrm{v} / \mathrm{v})$, inkubasi pada suhu $37^{\circ} \mathrm{C}$ selama 4 jam. Sebagai perlakuan, whey dan ekstrak buah ditambahkan sebanyak $3 \%$ pada saat formulasi. Yoghurt diuji mutunya yang meliputi total $\mathrm{BAL}, \mathrm{pH}$, dan adhesiveness. Semuanya diamati setiap jam. Total bakteri dihitung dengan menggunakan metode hitungan cawan dengan petrifilm. Nilai $\mathrm{pH}$ ditentukan dengan menggunakan $\mathrm{pH}$ meter elektronik, dan adhesiveness ditentukan menggunakan texture analyzer.

Perubahan BAL, $\mathrm{pH}$, dan adhesiveness selama fermentasi jam ke-0 hingga jam ke-4 dianalisis secara deskriptif. Analisis ini menjelaskan dinamika parameter sepanjang waktu proses fermentasi, sekaligus menunjukkan laju perubahannya selama fermentasi. Analisis ini diterapkan karena dinamika pertumbuhan inokulum selama fermentasi menentukan mutu produk yang dihasilkan, sesuai tujuan fermentasi (Stanbury et al., 1995).

\section{Hasil dan Pembahasan \\ Total BAL Yoghurt}

Rata-rata total BAL yoghurt dengan bahan baku susu sapi dan yoghurt dengan tambahan whey serta ekstrak buah selama fermentasi 4 jam ditampilkan pada
Tabel 1. Kajian mutu akhir produk menunjukkan bahwa perlakuan penambahan whey dan ekstrak buah tidak berpengaruh nyata $(P>0,05)$ terhadap total $B A L$ yoghurt. Setiap perlakuan menghasilkan total BAL yang memenuhi standar minimal sebesar $10^{7} \mathrm{CFU} / \mathrm{ml}$ (BSN, 2009). Hal ini menunjukkan bahwa bahan baku dan substrat yang digunakan dapat menghasilkan yoghurt dengan kualitas yang baik Kumalasari et al. (2012).

Selain menghasilkan total BAL yang memenuhi standar, penambahan whey dan ekstrak buah menimbulkan efek laju pertumbuhan inokulum yang berbeda-beda (Tabel 1). Laju pertumbuhan $(\mu)$ BAL yoghurt dengan ekstrak buah alpukat merupakan yang terbesar, 0,67 cfu/s. Dengan demikian, ekstrak buah alpukat dapat diharapkan untuk menghasilkan yoghurt dengan kualitas yang memenuhi standar SNI dengan relatif lebih cepat.

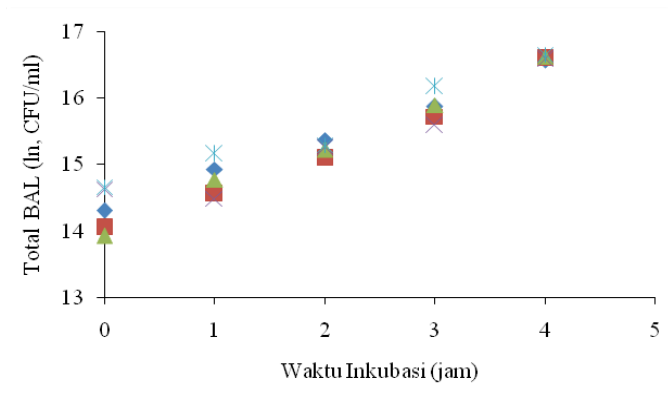

$\bullet 0 \%$ a $3 \%$ Whey $\triangle 3 \%$ Alpukat $\times 3 \%$ Salak $* 3 \%$ Kelengkeng

Grafik 1. Grafik Pertumbuhan Spesifik $(\mu)$ BAL Yoghurt dengan Bahan Susu Sapi, Susu Ditambah Whey 3\%, Susu Ditambah Ekstrak Buah Alpukat 3\%, Susu Ditambah Ekstrak Buah Salak 3\%, dan Susu Ditambah Ekstrak Buah Kelengkeng 3\%.

Tabel 1. Total BAL, Nilai Logaritma Natural (In), dan Nilai $(\mu)$ Pertumbuhan Spesifik (per jam) Yoghurt dengan Bahan Baku Susu Sapi, Susu Sapi Ditambah Whey, Susu Ditambah Ekstrak Buah Alpukat, Susu Ditambah Ekstrak Buah Salak, dan Susu Ditambah Ekstrak Buah Kelengkeng Kandungan Susu Segar

\begin{tabular}{|c|c|c|c|c|c|c|c|c|c|c|}
\hline \multirow{2}{*}{$\begin{array}{c}\text { Waktu Inkubasi } \\
\text { (jam) }\end{array}$} & \multicolumn{2}{|c|}{$\begin{array}{c}\text { Tanpa } \\
\text { Penambahan } \\
\end{array}$} & \multicolumn{2}{|c|}{ Cairan Whey } & \multicolumn{2}{|c|}{ Ekstrak Alpukat } & \multicolumn{2}{|c|}{ Ekstrak Salak } & \multicolumn{2}{|c|}{$\begin{array}{c}\text { Ekstrak } \\
\text { Kelengkeng }\end{array}$} \\
\hline & $B A L^{*}$ & In & $\mathrm{BAL}^{*}$ & In & $\mathrm{BAL}^{*}$ & In & $\mathrm{BAL}^{*}$ & In & $\mathrm{BAL}^{*}$ & In \\
\hline Jam ke-0 & $1,63 \times 10^{6}$ & 14,31 & $1,27 \times 10^{6}$ & 14,05 & $1,12 \times 10^{6}$ & 13,93 & $2,27 \times 10^{6}$ & 14,63 & $2,34 \times 10^{6}$ & 14,66 \\
\hline Jam ke-1 & $3,07 \times 10^{6}$ & 14,94 & $2,10 \times 10^{6}$ & 14,56 & $2,61 \times 10^{6}$ & 14,77 & $1,97 \times 10^{6}$ & 14,49 & $3,87 \times 10^{6}$ & 15,17 \\
\hline Jam ke-2 & $4,77 \times 10^{6}$ & 15,38 & $3,60 \times 10^{6}$ & 15,10 & $4,10 \times 10^{6}$ & 15,23 & $4,23 \times 10^{6}$ & 15,26 & $4,40 \times 10^{6}$ & 15,30 \\
\hline Jam ke-3 & $7,83 \times 10^{6}$ & 15,87 & $6,77 \times 10^{6}$ & 15,73 & $8,07 \times 10^{6}$ & 15,90 & $5,90 \times 10^{6}$ & 15,59 & $1,06 \times 10^{7}$ & 16,18 \\
\hline Jam ke-4 & $1,59 \times 10^{7}$ & 16,58 & $1,64 \times 10^{7}$ & 16,61 & $1,67 \times 10^{7}$ & 16,63 & $1,60 \times 10^{7}$ & 16,59 & $1,72 \times 10^{7}$ & 16,66 \\
\hline$m$ & & 0,56 & & 0,63 & & 0,67 & & 0,48 & & 0,49 \\
\hline
\end{tabular}

Keterangan : ${ }^{\star} \mathrm{CFU} / \mathrm{ml}$

Tabel 2. Nilai pH dan Adhesiveness Yoghurt dengan Bahan Baku Susu Sapi, Susu Sapi Ditambah Whey, Susu Ditambah Ekstrak Buah Alpukat, Susu Ditambah Ekstrak Buah Salak, dan Susu Ditambah Ekstrak Buah Kelengkeng Kandungan Susu Segar

\begin{tabular}{|c|c|c|c|c|c|c|c|c|c|c|}
\hline \multirow{2}{*}{$\begin{array}{c}\text { Waktu } \\
\text { Inkubasi } \\
\text { (jam) }\end{array}$} & \multicolumn{2}{|c|}{ Tanpa Penambahan } & \multicolumn{2}{|c|}{ Cairan Whey } & \multicolumn{2}{|c|}{ Ekstrak Alpukat } & \multicolumn{2}{|c|}{ Ekstrak Salak } & \multicolumn{2}{|c|}{ Ekstrak Kelengkeng } \\
\hline & $\mathrm{pH}$ & Adhesiveness & $\mathrm{pH}$ & Adhesiveness & $\mathrm{pH}$ & Adhesiveness & $\mathrm{pH}$ & Adhesiveness & $\mathrm{pH}$ & Adhesiveness \\
\hline Jam ke-1 & 6,14 & 0,30 & 5,97 & 0,20 & 5,88 & 0,18 & 5,97 & 0,32 & 5,99 & 0,33 \\
\hline Jam ke-2 & 5,69 & 1,40 & 5,63 & 1,08 & 5,72 & 1,23 & 5,53 & 1,27 & 5,66 & 1,40 \\
\hline Jam ke-4 & 4,78 & 2,97 & 5,11 & 2,57 & 4,61 & 3,13 & 4,69 & 2,70 & 4,68 & 3,13 \\
\hline
\end{tabular}


Plot nilai logaritma natural dari total BAL pada terhadap waktu menunjukkan dinamika fermentasi yang berlangsung (Grafik 1). Perubahan total BAL selama fermentasi 4 jam menandakan bahwa fermentasi berlangsung pada fase lag atau fase log. Fase pertumbuhan sebenarnya dari kedua fase yang mungkin tercapai tidak dapat ditentukan karena fermentasi berlangsung dalam waktu yang belum menunjukkan fase stasioner tercapai. Padahal, fase stasioner yang terobservasi dapat menjelaskan fase pertumbuhan sebelumnya (Srikandi, 1992; Stanbury et al., 1995).

\section{Nilai pH Yoghurt}

Nilai Rata-rata $\mathrm{pH}$ yoghurt dengan bahan baku susu sapi serta tambahan whey dan ekstrak buah ditampilkan pada Tabel 2. Nilai $\mathrm{pH}$ yang dicapai pada produk yoghurt sesuai dengan standar SNI dan tidak menunjukkan perbedaan yang nyata $(P>0,05)$ antara satu perlakuan dengan perlakuan lainnya.

Nilai $\mathrm{pH}$ ini relatif lebih tinggi dibandingkan nilai $\mathrm{pH}$ menurut Widodo (2002), yang menyebutkan bahwa nilai $\mathrm{pH}$ yang sebaiknya dicapai oleh yoghurt adalah sekitar 4,5. Hal ini dimungkinkan karena fermentasi yang relatif singkat pada suhu yang relatif lebih rendah sehingga asam belum banyak terakumulasi menimbulkan efek penurunan $\mathrm{pH}$.

\section{Adhesiveness Yoghurt}

Nilai rata-rata adhesiveness yoghurt dengan bahan baku susu sapi dan bahan tambahan berupa whey dan ekstrak buah ditampilkan pada Tabel 2. Nilai adhesiveness produk akhir dari yoghurt relatif rendah dibandingkan dengan nilai menurut pendapat Renata et al. (2006), yang menyatakan bahwa susu fermentasi berupa yogurt mempunyai tingkat adhesiveness sebesar 5,41 gs. Nilai adhesiveness menandakan kekentalan yoghurt. Nilai adhesiveness yang rendah pada penelitian ini dimungkinkan karena proses pembuatan yoghurt tidak melalui proses pasteurisasi untuk membunuh bakteri patogen karena diganti dengan penerapan sistem LPO. Padahal, pasteurisasi berperan penting dalam membentuk kekentalan yoghurt. Pasteurisasi berperan dalam mendenaturasi protein whey sehingga terbentuk jalinan dengan protein kasein yang berperan dalam memerangkap air untuk mengembangkan tekstur dan mencegah sineresis. Denaturasi semacam ini optimal terjadi pada pasteurisasi suhu $90-95^{\circ} \mathrm{C}$ selama 3-5 menit (Bylund, 1995).

\section{Kesimpulan}

Berdasarkan hasil penelitian dapat disimpulkan bahwa whey dan ekstrak buah dapat menghasilkan yoghurt dengan mutu BAL, pH sesuai standar SNI. Ekstrak buah alpukat sebanyak $3 \% \quad(\mathrm{v} / \mathrm{v})$ yang ditambahkan pada formula yoghurt bahkan menjanjikan laju pertumbuhan BAL yang lebih cepat sebesar 0,67 cfu/s dibandingkan ekstrak buah lain dan juga dibandingkan dengan whey.

\section{Daftar Pustaka}

Azizah, N., Y. B. Pramono dan S. B. M. Abduh. 2013. Sifat Fisik, Organoleptik, dan Kesukaan Yoghurt Drink dengan Penambahan Ekstrak Buah Nangka. Universitas Diponegoro Semarang. Jurnal Aplikasi Teknologi Pangan. 2 (3): 148-151.

Badan Standarisasi Nasional (BSN). 2009. Standar Nasional Indonesia 2981:2009 tentang Standar Mutu Yoghurt. Dewan Standarisasi NasionalDSN, Jakarta.

Bylund, G. 1995. Dairy Processing handbook. Sweden. Tetra Pak Processing System AB S-221.

Insyiroh, I., Masykuri dan S.B.M. Abduh. 2014. Nilai pH, Keasaman, Citarasa, dan Kesukaan Susu fermentasi dengan Penambahan Ekstrak Buah Nanas. Jurnal Aplikasi Teknologi Pangan Vol. 3 No. 3. Hal: 114-116.

Kumalasari, K. E. D. Nurwantoro dan S. Mulyani. 2012. Pengaruh Kombinasi Susu dengan Air Kelapa terhadap Total Bakteri Asam Laktat, Total Gula, dan Keasaman Yoghurt Drink. Universitas Diponegoro Semarang. Jurnal Aplikasi Teknologi Pangan 1 (2): 48-53.

Purbasari, A., Pramono, Y.B. dan S.B.M. Abduh. 2014. Nilai pH, Kekentalan, Citarasa Asam, dan Kesukaan pada Susu Fermentasi dengan Perisa Alami Jambu Air (Syzygium Sp). Jurnal Aplikasi Teknologi Pangan Vol. 3 No. 4. Hal: 174-177.

Puspitasari, I., Y.B. Pramono, Masykuri, Ahmad N. AlBaarri. 2014. Pengaruh Tingkat Penambahan Ekstrak Buah Kelengkeng terhadap $\mathrm{pH}$, Viskositas, Citarasa dan Kesukaan Yoghurt Kelengkeng. Jurnal Aplikasi Teknologi Pangan Vol. 3 No. 4. Hal: 164-167.

Renata B. M., E. S. Prudenncio, R. D. M. C. Amboni, N. G. C. Juni' or, R. V. B. Oliveira, V. Soldi and H. D. Benedit. 2006. Compositional and Physical Properties of Yogurts Manufactured from Milk and Whey Cheese Concentrated by Ultrafiltration. International Journal of Food Science and Technology 2006, 41 560-568.

Srikandi, F. 1992. Mikrobiologi Pangan 1. Jakarta. Gramedia

Stanbury, P. F., A. Whitaker and S. J. Hall. 1995. Principles of Fermentation Technology. Burlington. Butterworth-Heinemann.

Widodo, W. 2002. Bioteknologi Fermentasi Susu. Pusat Pengembangan Bioteknologi Universitas Muhammadiyah Malang, Malang. 